\title{
Cyclonic cold-core eddy in the eastern North Atlantic. II. Nutrients, phytoplankton and bacterioplankton*
}

\author{
K. Lochte ${ }^{1} \&$ O. Pfannkuche ${ }^{2}$ \\ ${ }^{1}$ Institut für Meereskunde an der Universität Kiel, Abteilung für Mikrobiologie, Düsternbrooker Weg 20, D-2300 Kiel, Federal \\ Republic of Germany \\ ${ }^{2}$ Institut für Hydrobiologie und Fischereiwissenschaft, Universität Hamburg, Zeiseweg 9, D-2000 Hamburg 50, Federal \\ Republic of Germany
}

\begin{abstract}
A cyclonic cold-core eddy in the Northeast Atlantic of about $100 \mathrm{~km}$ in diameter at the sea surface was investigated in May 1985, approximately 3 wk after it had separated from the Polar Front. A strong thermocline, which was shallower but more pronounced than in the ambient water, separated a warm surface layer within the eddy from deeper cold water, while horizontal salinity gradients marked the boundary to the ambient water. The cold-core eddy could be distinguished from ambient Northeast Atlantic water in terms of its nutrient chemistry, phytoplankton species distribution and abundance, bacterial numbers and cell size. The surface layer of the eddy was distinct from deeper eddy water, and was characterized by high concentrations of chlorophyll a, total phytoplankton biomass, dinoflagellates and bacteria. At the eddy's margin diatoms were predominant. It is argued that the physical isolation of the eddy surface layer due to the formation of a shallow thermocline led to rapid utilisation of nutrients. This probably enabled the development of a dinoflagellate-dominated phytoplankton population and of organisms capable of heterotrophic regenerative processes.
\end{abstract}

\section{INTRODUCTION}

In the world's oceans mesoscale rings or eddies occur where major currents and oceanic fronts are present. Their size ranges from tens to hundreds of kilometers and they can persist up to 1 or even 3 yr (Angel \& Fasham 1983). They separate from the respective current or front meander and move into water masses with different physical, chemical and biological characteristics. Thus, eddies may transport substantial amounts of nutrients and organic matter from one water mass into another (The Ring Group 1981). In the western part of the Atlantic Ocean cold and warm-core rings have been observed relatively frequently (review in Robinson 1983). The most extensive studies were carried out in rings of the Gulf Stream. These form regularly and, hence, provide good opportunities to study their influence on biology (Wiebe 1976, 1982, The Ring Group 1981).

\footnotetext{
- BIOTRANS Publication No. 2.
}

In the eastern part of the North Atlantic eddies have seldom been investigated (Le Groupe Tourbillon 1983, Kupferman et al. 1986, Mittelstaedt 1987 [preceding article]). They have only been studied with respect to their physical properties, but their impact on the distribution of nutrients, development and growth of planktonic organisms has not yet been described.

The mechanism of formation of a cyclonic cold-core eddy from a Polar Front meander has been described by Kupferman et al. (1986) and Mittelstaedt (1987). When it was first detected in April 1985, it had the form of a meander nearly $300 \mathrm{~km}$ long and only $40 \mathrm{~km}$ wide extending south-eastwards from the Polar Front (Kupferman et al. 1986). The eddy was found again in May 1985 during the cruise Meteor 70/III, when routine surveys of the programmes NOAMP (Nord-Ost Atlantisches Monitoring Programm) and BIOTRANS (BIOlogical vertical TRANSport and energetics in the benthic boundary layer of the deep sea) were carried out in this area. During this cruise it was possible to conduct a biological survey across the eddy along with the oceanographic investigations carried out by Mittel- 
staedt and coworkers. By the time of the present investigations the eddy had cut off from the Polar Front forming an isolated mesoscale feature. At the surface it had a diameter of about $100 \mathrm{~km}$ widening to about $200 \mathrm{~km}$ at greater depth (Mittelstaedt 1987). The oceanographic surveys showed that the eddy was evident down to a depth of at least $2500 \mathrm{~m}$ and possibly to even greater depths (Kupferman et al. 1986). Other eddies of the eastern North Atlantic could be detected down to $4000 \mathrm{~m}$ depth (Le Groupe Tourbillon 1983).

Our present biological survey represents the first description of horizontal and vertical distributions of nutrients, phytoplankton and bacterioplankton on a transect across a cold-core eddy in the Northeast Atlantic. Results suggest that the processes determining the phyto- and bacterioplankton abundances within the eddy are indeed different from the surrounding water mass.

\section{AREA OF INVESTIGATION}

During Meteor cruise 70/III, a transect from SW to NE across the mesoscale cold-core eddy was sampled at 5 locations for the biological survey. On the basis of the physical data the positions of the sampling stations relative to the eddy centre can be identified (Table 1).

Table 1. List of sampling stations and their water-mass characteristics

\begin{tabular}{|ccccl|}
\hline \multirow{2}{*}{ Stn } & Date & \multicolumn{2}{c|}{ Coordinates } & Water mass \\
& $(1985)$ & Lat. (N.) & Long. (W.) & \\
\hline 159 & 18 May & $48^{\circ} 14.2^{\prime}$ & $21^{\circ} 41.9^{\prime}$ & Ambient \\
161 & 19 May & $48^{\circ} 35.5^{\prime}$ & $21^{\circ} 21.2^{\prime}$ & Eddy centre \\
162 & 19 May & $48^{\circ} 50.0^{\prime}$ & $21^{\circ} 20.0^{\prime}$ & Eddy centre \\
163 & 19 May & $49^{\circ} 10.3^{\prime}$ & $21^{\circ} 15.8^{\prime}$ & Eddy margin \\
164 & 19 May & $49^{\circ} 31.4^{\prime}$ & $21^{\circ} 11.7^{\prime}$ & Ambient \\
170 & 22 May & $47^{\circ} 23.6^{\prime}$ & $19^{\circ} 39.8^{\prime}$ & Reference station \\
\hline
\end{tabular}

Stns 159 and 164 were situated in the ambient water but were possibly influenced by the eddy; Stn 163 was in the marginal area; Stns 161 and 162 represented the core of the eddy. A reference station (Stn 170) about $130 \mathrm{n}$ miles $(240 \mathrm{~km})$ to the south-southeast of the eddy centre and outside the eddy's influence was surveyed after completing the transect. The investigation was restricted to the upper $200 \mathrm{~m}$ of the water column.

\section{MATERIAL AND METHODS}

Temperature and salinity were measured by a conductivity-temperature-depth system (CTD); further details on the methodology and the physical oceano- graphy of the eddy are described by Mittelstaedt (1987). Zooplankton surveys are presented by Beckmann et al. (1987).

Nutrient concentrations as well as phyto- and bacterioplankton parameters were determined in water samples taken with Niskin sampling bottles, which had been cleaned with ethanol, at 10,20,50,100 and $200 \mathrm{~m}$ depth.

For chlorophyll analysis $500 \mathrm{ml}$ were filtered through $0.2 \mu \mathrm{m}$ membrane filters. The filters were homogenized and extracted with $90 \%$ acetone. Chlorophyll $a$ and phaeopigments were measured with a Turner Fluorometer following the method of Lorenzen (1967) and Shuman \& Lorenzen (1975).

Samples for nutrient analysis (nitrate, nitrite, orthophosphate, silicate) were stored frozen in glass bottles or, in the case of silicate, in polyethylene bottles. The nutrients were measured photometrically with a Technicon autoanalyzer after Technicon industrial method AA II (1973).

Phytoplankton organisms were microscopically counted by inverted microscopy after Utermöhl (1958) from $300 \mathrm{ml}$ water samples which had been preserved with $1 \%$ formalin. Organisms $\geq 50$ um were counted in the whole chamber and their sizes were measured individually. Organisms $\leq 50 \mu \mathrm{m}$ were enumerated in crossed transects through the chamber, and the sizes of a representative number of organisms of each species were measured. The counts also included small flagellated and unflagellated cells which may or may not contain photosynthetic pigments. They were classified into 3 size classes with diameters of $\leq 3 \mu \mathrm{m}, 3$ to $6 \mu \mathrm{m}$ and $\geq 6 \mu \mathrm{m}$, and are pooled in the following as 'nanoplankton' after the definition of Sieburth et al. (1978).

The biovolume for each species was determined according to the recommendations of Edler (1979). Total phytoplankton biomass was calculated assuming a conversion factor of $0.13 \mathrm{pg} \mathrm{C} \mu \mathrm{m}^{-3}$ for armoured dinoflagellates, and $0.11 \mathrm{pg} \mathrm{C} \mathrm{um}^{-3}$ for all other phytoplankton and nanoplankton (Edler 1979).

Total bacterial numbers were estimated by acridine orange epifluorescence direct counting technique based on recommendations by Daley \& Hobbie (1975), Jones \& Simon et al. (1975) and Hobbie et al. (1977) in $100 \mathrm{ml}$ samples preserved in $1 \%$ buffered and filtered formalin. Microscopic examination was carried out with a Zeiss Universal Epifluorescence Photomicroscope III using the filter combination KP 450-490, FT 510 , LP 520 at $\times 1250$ magnification. In each sample approximately 600 cells were counted and more than 200 cells were photographed using Ilford HP5 black and white films. The negative slides were projected onto a MOP AM02 digitizing board (Kontron Meßgeräte $\mathrm{GmbH}$, Munich, FRG), the length and width of at 
least 200 cells with sharp outlines were measured for each sample and the data were stored and handled on a Phillips P2000C personal computer. Cell volumes were calculated for each cell assuming geometrical shapes and these formed the basic data for the estimation of mean bacterial cell volume within each sample.

Bacterial cellular carbon was estimated from the biovolumes assuming a conversion factor of $0.106 \mathrm{pg} \mathrm{C}$ $\mu \mathrm{m}^{-3}$ (Nagata 1986). The frequency of dividing cells (FDC) was used to calculate bacterial growth rate applying the regression between FDC and growth rate of Hagström et al. (1979). Potential bacterial biomass production (PBBP) is the product of bacterial cellular carbon per volume of sample and growth rate (see also Turley \& Lochte 1985).

\section{RESULTS}

\section{Physical structure}

In the eddy centre at $40 \mathrm{~m}$ depth a distinct thermocline separated surface water from cold deep water while in the ambient water the thermocline was deeper and less well developed (Fig. 1a). Salinity was very

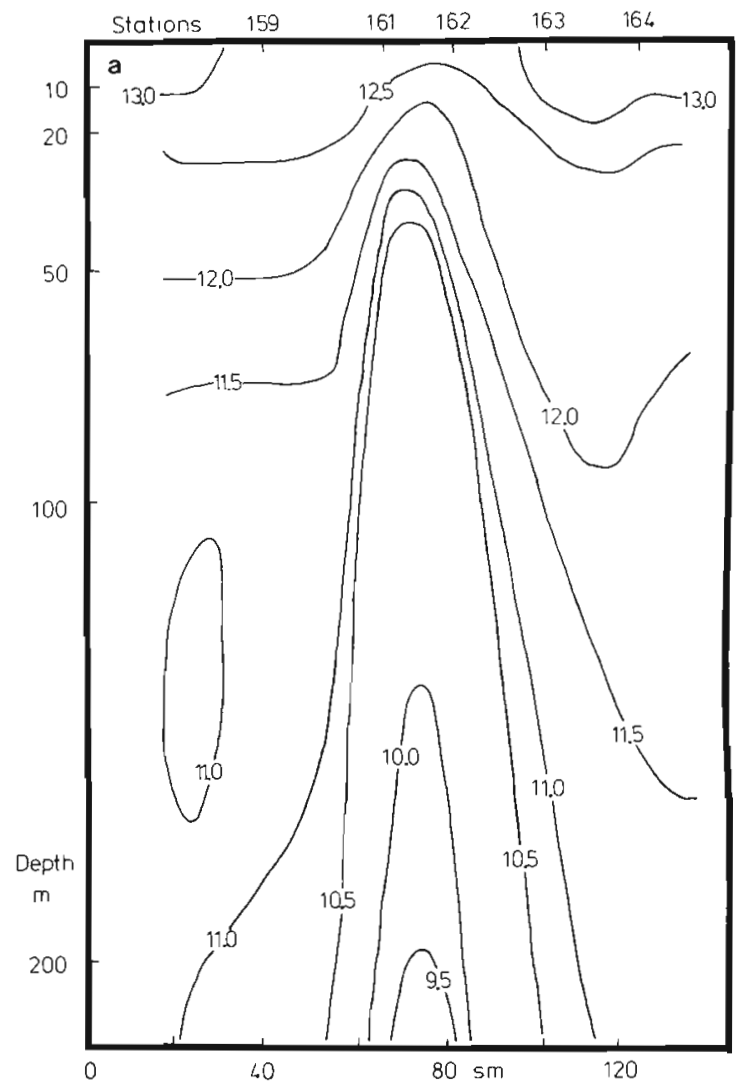

homogeneous in the centre of the eddy from the surface down to $200 \mathrm{~m}$. Its strong horizontal gradients delineated the boundary between the eddy and the ambient water mass (Fig. 1b).

\section{Distribution of nutrients}

All measured nutrient concentrations were lowest in the surface water of the eddy centre, however, below $50 \mathrm{~m}$ the water of the eddy core was richer in nutrients than in the ambient water and showed strong gradients at the margin. These horizontal gradients were probably related to the eddy's vertical physical structure. The low nitrate concentrations in the surface central waters of the eddy increased between 20 and $50 \mathrm{~m}$ in the vicinity of the eddy thermocline (Table 2, Fig. 2a). At the margin and in the surrounding water nitrate concentrations were higher by a factor of 3 . The values at the reference station (170) were similar to those found in the eddy core, except that here the increase in nitrate concentrations occurred below $50 \mathrm{~m}$ since the thermocline was also below $50 \mathrm{~m}$ at this station. Nitrite showed peaks at a depth of 50 or $100 \mathrm{~m}$ at most stations except at Stn 170, where concentrations were low

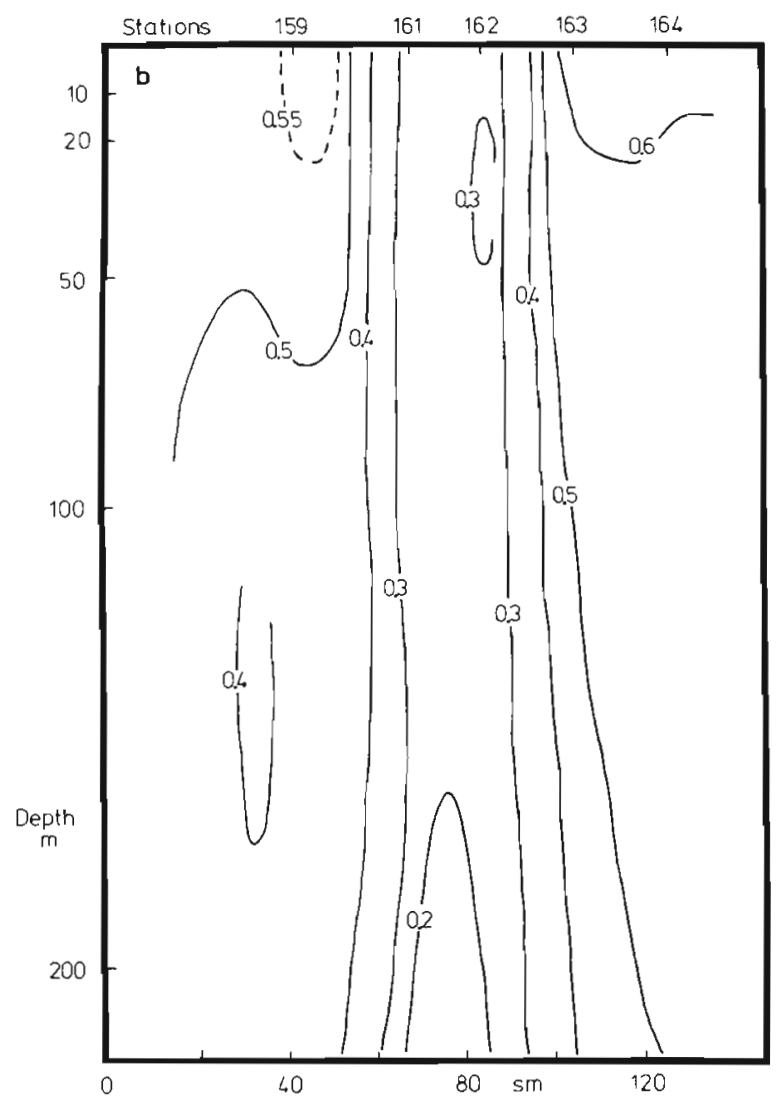

Fig. 1. Section across the upper $250 \mathrm{~m}$ of the cold-core eddy in the Northeast Atlantic in May 1985. Isopleths indicate (a) temperature $\left({ }^{\circ} \mathrm{C}\right.$ ) and (b) salinity (decimal fractions between 35 and $36 \%$ ). Redrawn from Mittelstaedt (1987) 
Table 2. Nutrient concentrations $\left(\mu \mathrm{mol} \mathrm{L^{-1 }}\right)$ at the eddy sampling stations and the reference station 170

\begin{tabular}{|c|c|c|c|c|c|}
\hline Stn & $\begin{array}{l}\text { Water depth } \\
\text { (m) }\end{array}$ & $\begin{array}{l}\text { Nitrite } \mathrm{NO}_{2}-\mathrm{N} \\
\quad\left(\mu \mathrm{mol} l^{-1}\right)\end{array}$ & $\begin{array}{l}\text { Nitrate } \mathrm{NO}_{3}-\mathrm{N} \\
\quad\left(\mu \mathrm{mol} \mathrm{l} \mathrm{l}^{-1}\right)\end{array}$ & $\begin{array}{c}\text { Phosphate } \mathrm{PO}_{4}-\mathrm{P} \\
\left(\mu \mathrm{mol} 1^{-1}\right)\end{array}$ & $\begin{array}{l}\text { Silicate } \mathrm{SiO}_{2}-\mathrm{Si} \\
\left(\mu \mathrm{mol} \mathrm{l^{-1 }}\right)\end{array}$ \\
\hline \multirow[t]{5}{*}{159} & 10 & 0.34 & 5.86 & 0.48 & ND \\
\hline & 20 & 0.36 & 4.14 & 0.45 & 2.14 \\
\hline & 50 & 0.56 & 7.36 & 0.58 & 3.21 \\
\hline & 100 & 0.19 & 14.86 & 0.68 & 3.93 \\
\hline & 200 & ND & 13.71 & 0.84 & 4.64 \\
\hline \multirow[t]{5}{*}{161} & 10 & 0.16 & 1.36 & 0.22 & ND \\
\hline & 20 & 0.30 & 5.43 & 0.32 & ND \\
\hline & 50 & 0.95 & 13.21 & 0.58 & 5.71 \\
\hline & 100 & 0.19 & 11.71 & 0.61 & 7.14 \\
\hline & 200 & ND & 18.29 & 0.71 & 10.36 \\
\hline \multirow[t]{5}{*}{162} & 10 & 0.10 & ND & 0.16 & ND \\
\hline & 20 & 0.18 & 2.00 & 0.39 & 1.43 \\
\hline & 50 & 1.04 & 6.07 & 0.61 & 2.86 \\
\hline & 100 & 0.56 & 11.71 & 0.74 & 4.29 \\
\hline & 200 & 0.56 & 16.07 & 0.94 & 6.07 \\
\hline \multirow[t]{5}{*}{163} & 10 & 0.34 & 5.21 & 0.29 & ND \\
\hline & 20 & 0.37 & 6.29 & 0.42 & ND \\
\hline & 50 & 0.50 & 6.57 & 0.42 & ND \\
\hline & 100 & 0.81 & 10.93 & 0.45 & 6.07 \\
\hline & 200 & 0.23 & 16.93 & 0.87 & 9.29 \\
\hline \multirow[t]{5}{*}{164} & 10 & 0.43 & 4.93 & 0.26 & ND \\
\hline & 20 & 0.56 & 6.50 & 0.45 & ND \\
\hline & 50 & 0.50 & 8.71 & 0.52 & 2.14 \\
\hline & 100 & 1.10 & 12.21 & 0.58 & 3.93 \\
\hline & 200 & 1.25 & 12.21 & 0.68 & 4.28 \\
\hline \multirow[t]{5}{*}{170} & 10 & 0.21 & 2.07 & 0.23 & 2.14 \\
\hline & 20 & 0.26 & 2.00 & 0.42 & 6.79 \\
\hline & 50 & 0.21 & 3.86 & 0.39 & 1.43 \\
\hline & 100 & 0.13 & 13.79 & 0.65 & 6.43 \\
\hline & 200 & 0.15 & 15.64 & 0.77 & 9.64 \\
\hline
\end{tabular}

throughout the upper $200 \mathrm{~m}$ (Table 2). Orthophosphate concentration was particularly low in the surface water of the eddy centre (Fig. 2b). Silicate concentrations were low in all the surface waters down to about $50 \mathrm{~m}$ (Fig. 2c). At the reference station more silicate was present especially in the surface water (Table 2).

\section{Distribution and composition of phytoplankton}

In the centre of the eddy, chlorophyll a concentration was highest above $20 \mathrm{~m}$ depth close to the surface. Here also occurred the highest surface-water phaeopigment concentrations, both absolute as well as

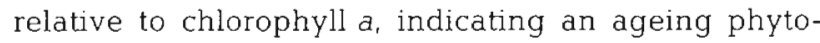
plankton population. Strong horizontal gradients of chlorophyll concentration towards the ambient water were apparent (Fig. 4a). They were higher by a factor of 3 than the concentrations in both the ambient water and at the reference station (Table 3 ). At the reference station, a deep chlorophyll maximum was present at $50 \mathrm{~m}$ depth.

Dinoflagellates, mainly Gymnodinium spp., reached their highest concentration of more than $4 \times 10^{5}$ cells $\mathrm{I}^{-1}$ in the eddy surface water at Stn 162 (Fig. 3a, Tabie 4). At Stn 164, in the ambient water, relatively high numbers of dinoflagellates occurred deeper than $50 \mathrm{~m}$, coinciding with the deepening of the thermocline at this station (Fig, 1a). At the reference station, the number and distribution of dinoflagellates was comparable to that of Stn 164 (Table 4).

In contrast to dinoflagellates, diatoms predominated in the eddy's margins (Fig. 3b). Nitzschia seriata, Chaetocerus compressus and $C$. affine were the most numerous species. A deep maximum of diatom cells occurred at $50 \mathrm{~m}$ depth at the reference station (Table 4). Diatoms and dinoflagellates did not occur in high numbers in the same area, rather one or the other group was characteristic of a certain water mass.

The depth profile of the total number of phytoplank- 


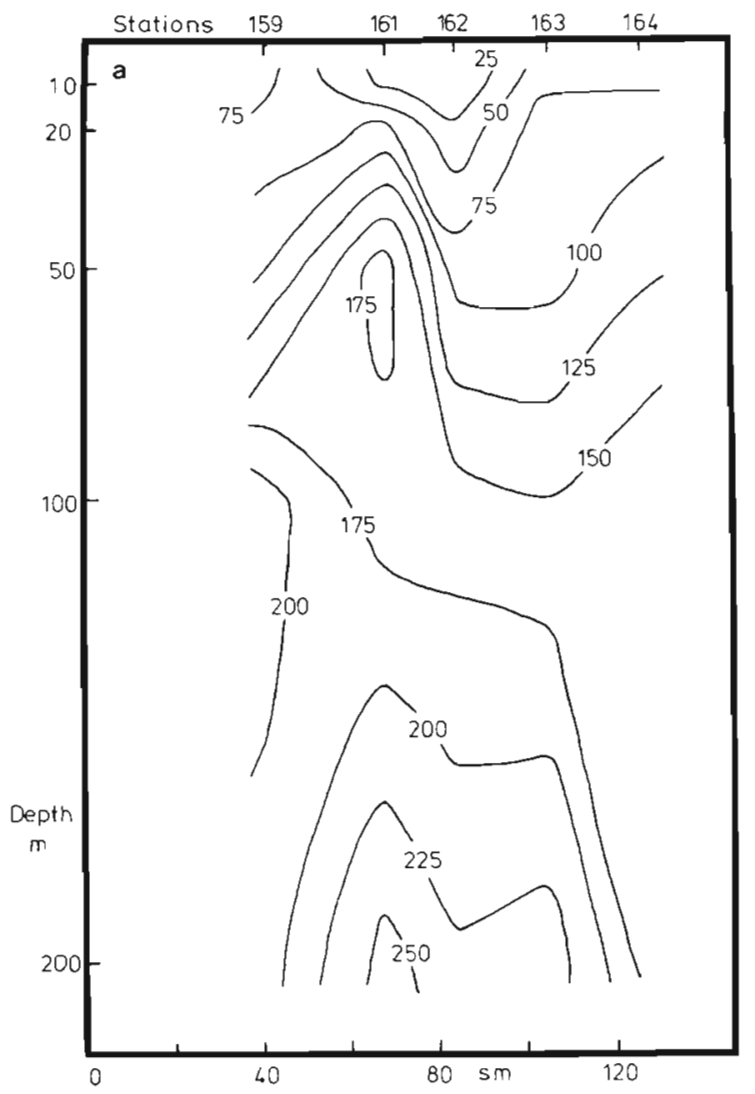

Fig. 2. Section across the cold-core eddy in the Northeast Atlantic in May 1985. Isopleths indicate the distributions of (a) nitrate concentrations ( $\mu \mathrm{g} \mathrm{NO}_{3}-\mathrm{N}^{-1}$ ), (b) orthophosphate concentrations $\left(\mu \mathrm{g} \mathrm{PO}_{4}-\mathrm{P}^{-1}\right)$, and (c) silicate concentrations ( $\mu \mathrm{g}$ $\left.\mathrm{SiO}_{4}-\mathrm{Si} \mathrm{l}{ }^{-1}\right)$

ton organisms shows that generally neither dinoflagellates nor diatoms but rather nanoplankton organisms dominated the distribution of total phytoplankton cells (Fig. 4b, Table 4). The highest numbers of cells were found at Stn 164, outside the eddy, even at greater depths. Since the small cells, despite their high numbers, contributed only little biomass, the distribution pattern of total phytoplankton biomass was determined mainly by the large dinoflagellates. Hence, in the surface water of the central eddy stations phytoplankton biomass was highest (Fig. 4c).

\section{Distribution of bacterial numbers, cell volume and bacterial production}

Bacterial numbers reached highest concentrations $\left(37 \times 10^{5}\right.$ cells Inl $\left.^{-1}\right)$ in the surface of the eddy centre, which is 1.3 to 1.7 times higher than in the marginal and ambient surface waters (Fig. 5a). Below the eddy thermocline they rapidly declined to less than a third or fifth of the surface values. At the reference station
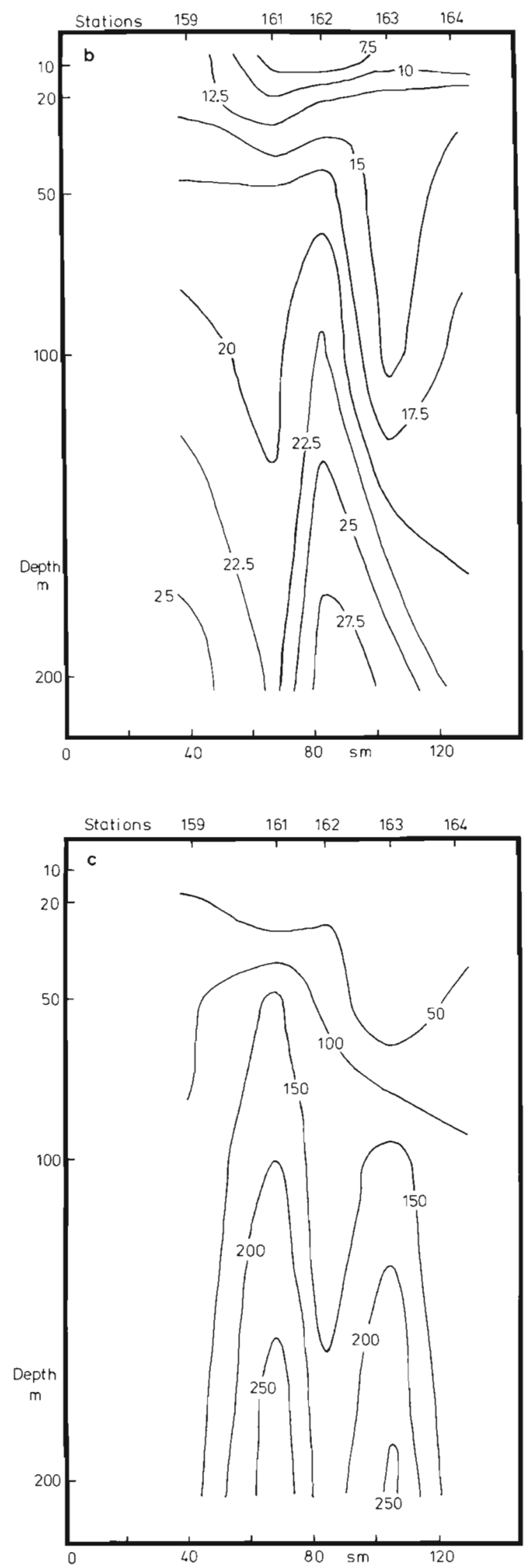


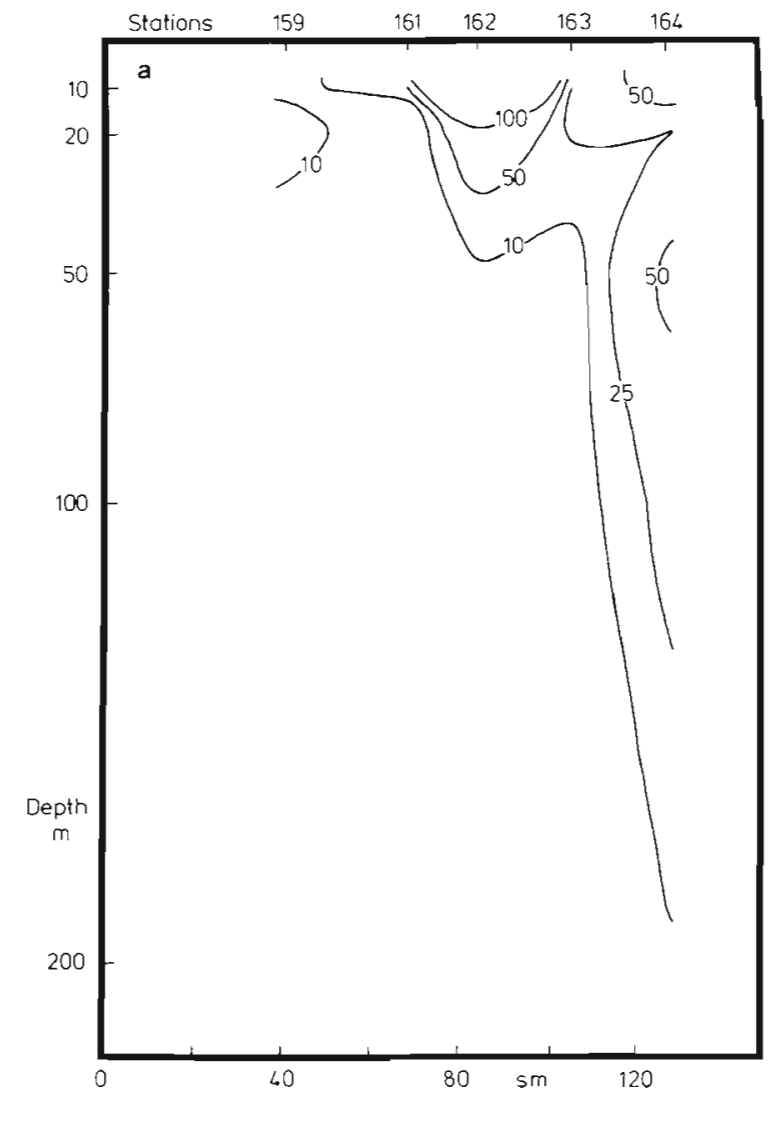

Table 3. Concentrations of chlorophyll $a$ and pheopigments across the eddy transect and at the reference station 170

\begin{tabular}{|c|c|c|c|}
\hline Stn & $\begin{array}{l}\text { Water depth } \\
(\mathrm{m})\end{array}$ & $\begin{array}{c}\text { Chlorophyll a } \\
\left(\mu g l^{-1}\right)\end{array}$ & $\begin{array}{c}\text { Pheopigments } \\
\left(\mu \mathrm{g} \mathrm{l}^{-1}\right)\end{array}$ \\
\hline \multirow[t]{5}{*}{159} & 10 & 2.01 & 0.57 \\
\hline & 20 & 1.71 & 0.61 \\
\hline & 50 & 0.47 & 0.12 \\
\hline & 100 & 0.03 & 0.06 \\
\hline & 200 & $\leq 0.01$ & 0.09 \\
\hline \multirow[t]{5}{*}{161} & 10 & 6.14 & 3.60 \\
\hline & 20 & 2.52 & 1.18 \\
\hline & 50 & 0.76 & 0.30 \\
\hline & 100 & 0.04 & 0.05 \\
\hline & 200 & 0.01 & 0.02 \\
\hline \multirow[t]{5}{*}{162} & 10 & 6.28 & 2.80 \\
\hline & 20 & 2.84 & 1.36 \\
\hline & 50 & 1.05 & 0.55 \\
\hline & 100 & 0.05 & 0.05 \\
\hline & 200 & 0.02 & 0.03 \\
\hline \multirow[t]{5}{*}{163} & 10 & 2.02 & 0.80 \\
\hline & 20 & 1.08 & 0.57 \\
\hline & 50 & 1.69 & 1.34 \\
\hline & 100 & 0.11 & 0.09 \\
\hline & 200 & 0.03 & 0.04 \\
\hline \multirow[t]{5}{*}{164} & 10 & 3.06 & 1.11 \\
\hline & 20 & 3.08 & 1.52 \\
\hline & 50 & 1.24 & 0.74 \\
\hline & 100 & 0.35 & 0.13 \\
\hline & 200 & 0.27 & 0.15 \\
\hline \multirow[t]{5}{*}{170} & 10 & 1.95 & 0.37 \\
\hline & 20 & 2.10 & 0.29 \\
\hline & 50 & 2.69 & 0.61 \\
\hline & 100 & 0.06 & 0.05 \\
\hline & 200 & 0.01 & 0.03 \\
\hline
\end{tabular}

bacterial numbers were comparable to those of the eddy margin or the ambient water (Table 5). The bacterial distribution pattern across the eddy was similar to that of dinoflagellates.

The precise analysis of bacterial cell sizes revealed that in the centre of the eddy smallest mean cell volumes were found ranging from 0.049 to $0.076 \mu \mathrm{m}^{3}$ (Fig. $5 b)$. However, in contrast to bacterial numbers, low mean cell volumes were present not only in the surface water but throughout the water column in the eddy centre. Towards the eddy margin and the ambient water the mean cell volumes gradually increased to 0.080 to $0.098 \mathrm{um}^{3}$, and largest mean cell volumes up to $0.114 \mu \mathrm{m}^{3}$ were found at the reference station 170 (Table 5).

Fig. 3. Section across the cold-core eddy in the Northeast Atlantic in May 1985. Isopleths indicate the distribution of (a) numbers of dinoflagellates $\left(10^{3}\right.$ cells $\left.1^{-1}\right)$ and (b) numbers of diatoms $\left(10^{5}{\left.\text { cells } 1^{-1}\right)}^{-1}\right.$ 
Table 4. Phytoplankton composition, abundance and biomass across the eddy transect and at the reference station 170

\begin{tabular}{|c|c|c|c|c|c|c|c|}
\hline Stn & $\begin{array}{l}\text { Water depth } \\
\text { (m) }\end{array}$ & $\begin{array}{c}\text { Diatoms } \\
\left(\text { cells } 1^{-1} \times 10^{5}\right)\end{array}$ & $\begin{array}{l}\text { Dinoflagellates } \\
\left(\text { cells } l^{-1} \times 10^{3} \text { ) }\right.\end{array}$ & $\begin{array}{l}\text { Nanoplankton } \\
\left(\text { cells } 1^{-1} \times 10^{5}\right)\end{array}$ & $\begin{array}{c}\text { Other cells } \\
\left(\text { cells } 1^{-1} \times 10^{3}\right)\end{array}$ & $\begin{array}{c}\sum \text { cells } \\
\left(\text { cells } l^{-1} \times 10^{5}\right)\end{array}$ & $\begin{array}{c}\text { Total biomass } \\
\quad\left(\mu \mathrm{gC} \mathrm{l}^{-1}\right)\end{array}$ \\
\hline \multirow[t]{5}{*}{159} & 10 & 22.42 & 7.70 & 11.89 & ND & 34.39 & 145.85 \\
\hline & 20 & 15.72 & 14.99 & 13.86 & 0.28 & 29.75 & 150.74 \\
\hline & 50 & 1.44 & 0.22 & 18.97 & 0.10 & 20.41 & 12.74 \\
\hline & 100 & 0.02 & $\mathrm{ND}$ & 19.88 & 0.51 & 19.92 & 3.14 \\
\hline & 200 & 0.04 & $\mathrm{ND}$ & 17.25 & ND & 17.29 & 1.98 \\
\hline \multirow[t]{5}{*}{161} & 10 & 11.70 & 147.00 & 38.35 & 13.38 & 51.66 & 197.48 \\
\hline & 20 & 18.13 & 0.20 & 17.24 & 0.04 & 35.39 & 109.88 \\
\hline & 50 & 1.03 & 0.02 & 31.95 & 0.08 & 32.99 & 14.96 \\
\hline & 100 & $\leq 0.01$ & ND & 10.19 & 0.14 & 10.19 & 2.26 \\
\hline & 200 & $\leq 0.01$ & ND & 17.74 & 1.50 & 17.76 & 2.24 \\
\hline \multirow[t]{5}{*}{162} & 10 & 7.84 & 454.07 & 45.80 & 5.28 & 58.27 & 213.39 \\
\hline & 20 & 9.19 & 96.70 & 25.05 & 0.97 & 35.22 & 73.20 \\
\hline & 50 & 3.70 & 0.02 & 16.84 & 27.51 & 20.82 & 36.99 \\
\hline & 100 & $\leq 0.01$ & 0.10 & 15.17 & 0.04 & 15.27 & 2.95 \\
\hline & 200 & $\leq 0.01$ & ND & 12.46 & ND & 12.49 & 2.09 \\
\hline \multirow[t]{5}{*}{163} & 10 & 21.13 & 25.50 & 36.54 & 4.51 & 57.98 & 180.39 \\
\hline & 20 & 9.21 & 27.04 & 46.14 & 6.79 & 55.70 & 72.18 \\
\hline & 50 & 10.33 & 8.87 & 37.27 & 3.49 & 47.72 & 77.38 \\
\hline & 100 & 0.06 & 0.16 & 15.40 & 0.08 & 15.47 & 4.37 \\
\hline & 200 & 0.02 & $N D$ & 20.25 & 0.06 & 20.27 & 4.57 \\
\hline \multirow[t]{5}{*}{164} & 10 & 13.24 & 65.79 & 190.08 & 0.42 & 203.98 & 121.10 \\
\hline & 20 & 16.68 & 24.93 & 145.03 & 0.73 & 161.97 & 115.08 \\
\hline & 50 & 12.07 & 55.22 & 41.00 & 1.69 & 53.65 & 76.26 \\
\hline & 100 & 1.10 & 30.92 & 35.77 & ND & 37.18 & 18.12 \\
\hline & 200 & 1.09 & 7.13 & 18.63 & 1.83 & 20.70 & 28.12 \\
\hline \multirow[t]{5}{*}{170} & 10 & 8.00 & 67.10 & 116.85 & 0.07 & 125.52 & 88.97 \\
\hline & 20 & 6.64 & 92.54 & 87.27 & 0.07 & 94.81 & 84.69 \\
\hline & 50 & 28.33 & 46.99 & 147.29 & 0.14 & 176.09 & 305.44 \\
\hline & 100 & 0.03 & 31.38 & 24.20 & 0.04 & 24.55 & 5.08 \\
\hline & 200 & 0.02 & 15.64 & 25.81 & ND & 25.99 & 4.60 \\
\hline
\end{tabular}

Bacterial biomass showed an essentially similar distribution pattern to bacterial numbers (Table 5). In the eddy surface water $24 \mu \mathrm{g} \mathrm{Cl} \mathrm{l}^{-1}$ was estimated, which amounts to approximately $10 \%$ of the total phytoplankton biomass (Table 4). Below the thermocline in the eddy centre as well as in the ambient water mass bacterial biomass decreased rapidly, but despite this, in these deep waters it was about equal to total phytoplankton biomass. No distinct differences of FDC or PBBP between eddy and surrounding water were apparent (Table 5).

\section{DISCUSSION}

\section{Physical conditions}

This survey of the cold-core eddy provides a biological 'snapshot' of the standing stocks of nutrients and planktonic organisms of a relatively young eddy. Approximately $3 \mathrm{wk}$ earlier the eddy was still con- nected to the Polar Front and receiving new water input from it (Kupferman et al. 1986). At the time of our investigation the eddy core above $30 \mathrm{~m}$ had warmed by about $2 \mathrm{C}^{\circ}$ since the investigation of Kupferman et al. (1986) to temperatures close to those of the ambient water. Since salinity still showed strong gradients towards the ambient water and was uniform down to $250 \mathrm{~m}$ (Fig. 1), the rise in temperature can be attributed to solar surface heating rather than lateral mixing processes.

The distribution patterns of several parameters, especially of temperature (Fig. 1a), orthophosphate (Fig. 2b), dinoflagellates (Fig. 3a) and total phytoplankton numbers (Fig. 4b) show that at Stn 164 the surface values persisted into greater depth than at other stations. This may indicate some degree of downwelling or rather vertical mixing at this station, as here highest geostrophic velocities were estinnated for the upper part of the water column down to about $250 \mathrm{~m}$ depth (Mittelstaedt 1987). 

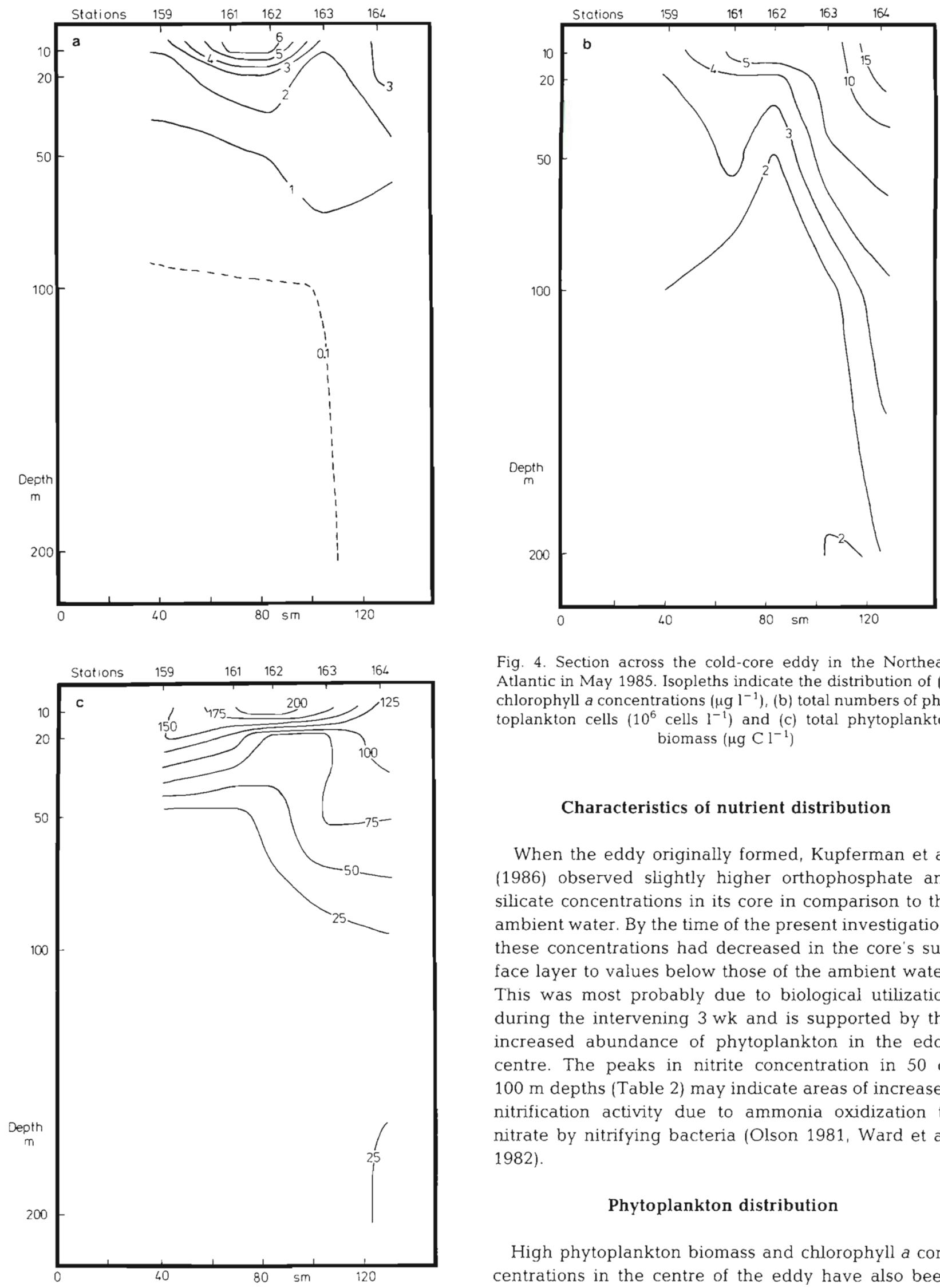

Fig. 4. Section across the cold-core eddy in the Northeast Atlantic in May 1985. Isopleths indicate the distribution of (a) chlorophyll a concentrations $\left(\mu \mathrm{g} \mathrm{l}^{-1}\right)$, (b) total numbers of phytoplankton cells $\left(10^{6}\right.$ cells $\left.1^{-1}\right)$ and (c) total phytoplankton biomass $\left(\mu \mathrm{g} \mathrm{Cl}^{-1}\right.$ )

\section{Characteristics of nutrient distribution}

When the eddy originally formed, Kupferman et al. (1986) observed slightly higher orthophosphate and silicate concentrations in its core in comparison to the ambient water. By the time of the present investigation, these concentrations had decreased in the core's surface layer to values below those of the ambient water. This was most probably due to biological utilization during the intervening $3 \mathrm{wk}$ and is supported by the increased abundance of phytoplankton in the eddy centre. The peaks in nitrite concentration in 50 or $100 \mathrm{~m}$ depths (Table 2) may indicate areas of increased nitrification activity due to ammonia oxidization to nitrate by nitrifying bacteria (Olson 1981, Ward et al. 1982).

\section{Phytoplankton distribution}

High phytoplankton biomass and chlorophyll a concentrations in the centre of the eddy have also been 
Table 5. Bacterial numbers and biomass across the eddy transect and at the reference station 170. MCV mean cell volume; FDC: frequency of dividing cells; PBBP: potential bacterial biomass production

\begin{tabular}{|c|c|c|c|c|c|c|}
\hline Stn & Water depth (m) & $\begin{array}{c}\text { Bacteria } \\
\text { (cells } \mathrm{ml}^{-1} \times 10^{5} \text { ) }\end{array}$ & $\operatorname{MCV}\left(\mu \mathrm{m}^{3}\right)$ & $\begin{array}{l}\text { Bacterial biomass } \\
\quad\left(\text { ug } C \mathrm{l}^{-1}\right)\end{array}$ & $\operatorname{FDC}(\%)$ & $\begin{array}{c}\text { PBBP } \\
\mu \mathrm{gC} \mathrm{l}^{-1} \mathrm{~d}^{-1}\end{array}$ \\
\hline 159 & $\begin{array}{r}10 \\
20 \\
50 \\
100 \\
200\end{array}$ & $\begin{array}{r}21.92 \\
23.32 \\
9.13 \\
4.15 \\
2.09\end{array}$ & $\begin{array}{l}0.091 \\
0.080 \\
0.084 \\
0.080 \\
0.096\end{array}$ & $\begin{array}{r}19.95 \\
18.66 \\
7.67 \\
3.32 \\
2.01\end{array}$ & $\begin{array}{l}1.66 \\
3.26 \\
2.00 \\
1.30 \\
2.32\end{array}$ & $\begin{array}{r}6.52 \\
14.50 \\
3.24 \\
0.75 \\
1.03\end{array}$ \\
\hline 161 & $\begin{array}{r}10 \\
20 \\
50 \\
100 \\
200\end{array}$ & $\begin{array}{r}37.27 \\
31.63 \\
8.74 \\
3.16 \\
3.84\end{array}$ & $\begin{array}{l}0.067 \\
0.049 \\
0.059 \\
0.062 \\
0.090\end{array}$ & $\begin{array}{r}24.97 \\
15.51 \\
5.15 \\
1.96 \\
3.46\end{array}$ & $\begin{array}{l}1.55 \\
1.92 \\
2.32 \\
1.19 \\
1.27\end{array}$ & $\begin{array}{l}7.39 \\
6.20 \\
2.64 \\
0.38 \\
0.75\end{array}$ \\
\hline 162 & $\begin{array}{r}10 \\
20 \\
50 \\
100 \\
200\end{array}$ & $\begin{array}{r}33.83 \\
33.38 \\
11.69 \\
5.17 \\
2.67\end{array}$ & $\begin{array}{l}0.071 \\
0.067 \\
0.077 \\
0.075 \\
0.076\end{array}$ & $\begin{array}{r}24.02 \\
22.36 \\
9.00 \\
3.88 \\
2.03\end{array}$ & $\begin{array}{l}2.25 \\
1.73 \\
0.95 \\
1.18 \\
1.07\end{array}$ & $\begin{array}{r}11.82 \\
7.75 \\
1.15 \\
0.74 \\
0.33\end{array}$ \\
\hline 163 & $\begin{array}{r}10 \\
20 \\
50 \\
100 \\
200\end{array}$ & $\begin{array}{r}10.27 \\
21.98 \\
15.11 \\
4.27 \\
4.52\end{array}$ & $\begin{array}{l}0.087 \\
0.098 \\
0.081 \\
0.082 \\
0.086\end{array}$ & $\begin{array}{r}8.93 \\
21.54 \\
12.24 \\
3.50 \\
3.89\end{array}$ & $\begin{array}{l}0.86 \\
2.21 \\
1.14 \\
1.42 \\
0.40\end{array}$ & $\begin{array}{r}0.91 \\
10.38 \\
2.21 \\
0.91 \\
-0.11\end{array}$ \\
\hline 164 & $\begin{array}{r}10 \\
20 \\
50 \\
100 \\
200\end{array}$ & $\begin{array}{r}27.94 \\
17.87 \\
8.10 \\
5.79 \\
5.00\end{array}$ & $\begin{array}{l}0.098 \\
0.093 \\
0.080 \\
0.075 \\
0.088\end{array}$ & $\begin{array}{r}27.38 \\
16.62 \\
6.48 \\
4.34 \\
4.40\end{array}$ & $\begin{array}{l}2.18 \\
1.41 \\
0.38 \\
0.52 \\
0.61\end{array}$ & $\begin{array}{r}12.93 \\
4.26 \\
-0.23 \\
0.02 \\
0.13\end{array}$ \\
\hline 170 & $\begin{array}{r}10 \\
20 \\
50 \\
100 \\
200\end{array}$ & $\begin{array}{r}18.97 \\
21.13 \\
19.79 \\
3.27 \\
2.41\end{array}$ & $\begin{array}{l}0.114 \\
0.095 \\
0.085 \\
0.107 \\
0.104\end{array}$ & $\begin{array}{r}21.63 \\
18.80 \\
2.78 \\
2.58 \\
2.51\end{array}$ & $\begin{array}{l}1.90 \\
0.58 \\
0.36 \\
0.67 \\
1.34\end{array}$ & $\begin{array}{r}8.53 \\
0.43 \\
-0.66 \\
0.17 \\
0.59\end{array}$ \\
\hline
\end{tabular}

observed in relatively young cold-core rings of the Gulf Stream. This was due to the enclosure of continental slope water which is generally richer in nutrients and biomass than the surrounding Sargasso Sea (Ortner et al. 1979). The difference between ring core water and ambient water was apparent for up to 1 to 3 mo (The Ring Group 1981). Due to surface heating and mixing processes a decline of phytoplankton and zooplankton in the surface water ensued in older cold-core rings (Wiebe 1976, The Ring Group 1981). Hence, our biological observations are consistent with oceanographic evidence, in that the investigated eddy was approximately only 1 mo old (Mittelstaedt 1987).

Ortner et al. (1979) found that phytoplankton species composition in Gulf Stream cold-core rings was different from both the Sargasso Sea and the continental slope water. This implies that the population within the ring underwent a different development to that in the original water mass. Higher concentrations of some dinoflagellate and coccolithophore species, but reduced numbers of diatoms, were found within the ring in comparison to Sargasso Sea water (Ortner et al. 1979). Our study of the eddy in the Northeast Atlantic also showed high concentrations of dinoflagellates in the centre, while diatoms were more numerous at the margin of the eddy. An increased input of silicate and other nutrients at the ring's margin, where highest rotational velocities were found, may have been the cause for the higher numbers of diatoms. The reverse situation to cold-core rings was found in warm-core Gulf Stream rings, where Fryxell et al. (1985) observed higher numbers of dinoflagellates in the high velocity region than in the ring's center, while diatoms seemed more numerous in the ring core (see also Nelson et al. 1985). These contrasting observations are likely to be caused by different development patterns in warmcore rings, which show a gradual increase in biomass in the course of interaction with ambient continental slope water (Hitchcock et al. 1985, Nelson et al. 1985), as compared to cold-core rings, which usually decrease in plankton biomass during their ageing.

At the reference station the highest number of 

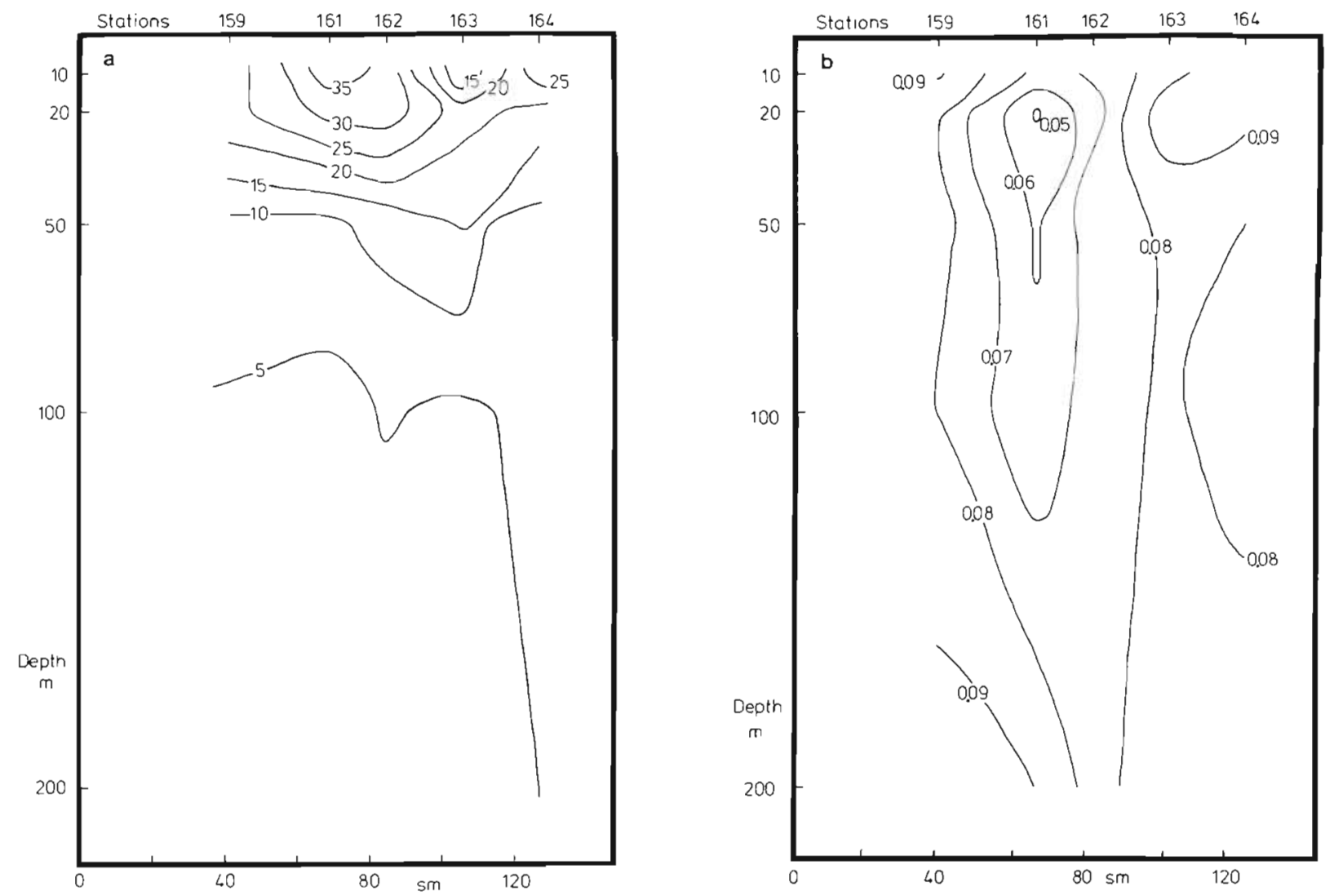

Fig. 5. Section across the cold-core eddy in the Northeast Atlantic in May 1985. Isopleths indicate the distribution of (a) numbers of bacteria $\left(10^{5}\right.$ cells $\left.\mathrm{ml}^{-1}\right)$ and $(b)$ mean bacterial cell volumes $\left(\mu \mathrm{m}^{3}\right)$

diatom cells was found at a depth of $50 \mathrm{~m}$. This may be the depth where the balance between light and diffusion of silicate, nitrate and phosphate through the thermocline was optimal for diatom growth. The low number of dinoflagellates at this station indicates that the typical summer situation of stratified water, characterised by high proportions of dinoflagellates, flagellates and heterotrophic organisms (Holligan et al. $1984 \mathrm{a}, \mathrm{b})$, had not yet developed in the water masses outside the eddy.

Extremely high concentrations of nanoplankton were evident at Stn 164 and also at the reference station 170 (Table 4). In the surface water of the eddy centre less than $8 \%$ of the total phytoplankton biomass was made up by nanoplankton, while at Stns 163, 164 and 170 they contributed 14 to $27 \%$. Nelson et al. (1985) described high abundance of nanoplankton and bacteria in regions of highest rotational velocity of a warmcore ring, but the reasons for this distribution are not quite clear. Since no distinction was made between phototrophic or heterotrophic cells, the implications of our observation are difficult to assess. In this context, it is noteworthy that integration of total phytoplankton biomass over all sampling depths leads to highest values at Stns 164 and 170 . This is not the case when chlorophyll a measurements are integrated. Hence, it is likely that many of the small cells, which are included in the estimation of total phytoplankton biomass, were free of pigments and were in fact heterotrophic organisms.

\section{Bacterial distribution}

Hanson et al. (1986) observed no difference in bacterial numbers between ambient water and a cold-core ring. In contrast to this, higher bacterial numbers were found towards the margin of warm-core rings (Ducklow 1984, Nelson et al. 1985, Peele et al. 1985). This was attributed to interaction between the cold continental slope water with the water of the ring. Since in our investigation no data were gathered at the Polar Front, it is difficult to ascertain whether the high bacterial numbers in the centre of the Northeast Atlantic eddy were characteristic for the original water mass from which the eddy was formed, or whether they developed within the eddy. However, the simultaneous occurrence of high bacterial numbers, dinoflagellate abundance, and the relatively high proportion of phaeopigments is characteristic for summer stratified waters, when the planktonic population produces and 
thrives on regenerated nutrients (Holligan et al. 1984a, b, Lochte 1985, Lochte \& Turley 1985). This is particularly interesting because in the ambient waters or at the reference station signs of the spring diatom bloom could still be found. There are 2 explanations for the more 'mature' stage of the plankton population in the eddy centre: (1) the original water mass at the Polar Front was already more advanced in comparison to the North Atlantic water, or (2) due to the physical isolation of a relatively small portion of water in the centre of the eddy by a very shallow thermocline not deeper than the euphotic zone, available nutrients were utilized more rapidly, thereby speeding up the seasonal progression. As the shallow thermocline only developed since the detachment of the eddy from the Polar Front, a more rapid seasonal development seems the more likely explanation.

Despite higher bacterial numbers the bacterial biomass in the eddy centre was not significantly higher than in the surrounding water mass or at the reference station, because of the relatively small cell sizes in the central water mass (Fig. 5b, Table 5). Cell size may be influenced either by nutritional conditions, bacterial growth patterns, selective grazing of large cells, or species composition (Novitsky \& Morita 1978, Andersson et al. 1986, Turley \& Lochte 1986, Turley et al. 1986). These processes are not mutually exclusive. However, despite higher phytoplankton biomass and, therefore, higher organic nutrient supply in the surface layer than in deeper water, bacterial mean cell size was consistently smaller throughout the top $200 \mathrm{~m}$ of the eddy centre. The small cell sizes within the eddy core may, therefore, indicate a different species composition within the eddy, which may have originated from Polar Front waters.

The estimates of PBBP (Table 5) imply that despite higher bacterial numbers in the centre of the eddy the bacterial productivity was not greater there than in the ambient water mass. Both in cold-core and warm-core rings increased bacterial production was measured in areas where the ring water interacted with the ambient water (Peele et al. 1985, Hanson et al. 1986). However, Hanson et al. (1986) observed that the response to changes in the environment may result in unbalanced growth, i.e. in some cases increased DNA production was found while in others RNA production was higher.

\section{Hypothesis for biological development within a cold- core eddy}

Due to the dynamic development of the planktonic population the biological characteristics of an eddy are likely to change at different rates compared to the physical or conservative chemical properties. Angel \& Fasham (1983) suggest that the biological effects of mesoscale eddies will, amongst other factors, be determined by the response time of planktonic organisms, and that phytoplankton and microplankton theoretically should have short enough a response time to maintain themselves within the eddy by their net population growth rates against diffusive processes. The present investigation showed that the phytoplankton and bacteria had indeed higher abundances, different composition and different distribution patterns within the eddy as compared to the ambient waters. It should be emphasized that the front surrounding the eddy is also an area of particular interest since the interaction of the different water masses may stimulate the development of certain types of organisms, like diatoms here, but may also cause death to others.

The investigation of the cold-core eddy was restricted to few stations and a short period of time, which does not allow for general conclusions. However, taking the above observations it may be possible to formulate a working hypothesis on the biological events within the eddy which led to the given distribution of planktonic organisms. When the eddy became detached from the Polar Front a development of phytoplankton organisms in the then nutrient-richer waters of the eddy ensued. The strong horizontal salinity gradient surrounding the central part of the eddy as well as the horizontal thermocline at around $40 \mathrm{~m}$ depth within the eddy core caused some degree of isolation of this lens of water from fresh nutrient input from the surrounding Atlantic water or the deep eddy water. Silicate depletion enforced a shift from a diatom-dominated population to a 'post-spring-bloom' population containing higher numbers of dinoflagellates and bacteria in the central surface water of the eddy, before such development took place in the ambient water. Regenerative processes by heterotrophs enabled the maintenance of the relatively high phytoplankton standing stock containing organisms which are able to utilize, and depend on, regenerated nutrients. At the eddy's margin mixing processes provided some input of silicate to sustain a diatom-dominated population.

Since our investigation another eddy was observed and investigated in the same region in 1986 (Stienen pers. comm.).
Acknowledgements. Our thanks are due to Dr Mittelstaedt (Deutsches Hydrographisches Institut) and the master and the crew of the RV Meteor for their help and cooperation. For their assistance we thank C. Pilnay (phytoplankton counts) and F. Dreyer (bacterial counts). For valuable criticism of the manuscript we are grateful to Dr C. M. Turley (IMER, Plymouth, UK). This investigation was funded by the Minister of Science and Technology of the Federal Republic of Germany (MFU 0544/9). 


\section{LITERATURE CITED}

Andersson, A., Larsson, U., Hagström, А. (1986). Size-selective grazing by a microflagellate on pelagic bacteria. Mar. Ecol. Prog. Ser. 33: 51-57

Angel, M. V., Fasham, M. J. R. (1983). Eddies in biological processes. In: Robinson, A. R. (ed.) Eddies in marine science. Springer-Verlag, Berlin, p. 492-524

Beckmann, W., Auras, A., Hemleben, C. (1987). Cyclonic coldcore eddy in the eastern North Atlantic. III. Zooplankton Mar. Ecol. Prog. Ser. 39: 165-173

Daley, R. J., Hobbie, J. E. (1975). Direct counts of aquatic bacteria by a modified epifluorescence technique. Limnol. Oceanogr. 20: 875-882

Ducklow, H. W. (1984). Geographical ecology of marine bacteria: physical and biological activity at the mesoscale. In: Reddy, C. A., Klug, M. J. (ed.) Current perspectives in microbial ecology. Am. Soc. Microbiol., Washington, D. C., p. $22-32$

Edler, L. (1979). Recommendations for marine biological studies in the Baltic Sea. Phytoplankton and chlorophyll Balt. Mar. Biol. Public. 5: 1-38

Fryxell, G. A., Gould, R. W., Balmori, E. R., Theriot, E. C. (1985). Gulf Stream warm core rings: phytoplankton in two fall rings of different ages. J. Plankton Res. 7: 339-364

Hagström, A., Larsson, U., Hörstedt, P., Normark, S. (1979). Frequency of dividing cells, a new approach to the determination of bacterial growth rates in aquatic environments. Appl, environ. Microbiol. 37: 805-812

Hanson, R. B., Pomeroy, L. R., Murray, R. E. (1986). Microbial growth rates in a cold-core Gulf Stream eddy of the northwestern Sargasso Sea. Deep-Sea Res. 33: 427-446

Hitchcock, G. L., Langdon, C., Smayda, T J. (1985). Seasonal variations in the phytoplankton biomass and productivity of a warm-core Gulf Stream ring. Deep-Sea Res. 32 $1287-1300$

Hobbie, J. E., Daley, R. J., Jasper, S. (1977). Use of nuclepore filters for counting bacteria by fluorescence microscopy. Appl. environ. Microbiol. 33: 1225-1228

Holligan, P. M., Harris, R. P., Newell, R. C., Harbour, D. S. Head, R. N., Linley, E. A. S., Lucas, M. I., Tranter, P. R. G., Weekley, C. M. (1984a). Vertical distribution and partitioning of organic carbon in mixed, frontal and stratified waters of the English Channel. Mar. Ecol. Prog. Ser. 14: 111-127

Holligan, P. M., Williams, P. J. leB., Purdie, D., Harries, R. P. (1984b). Photosynthesis, respiration and nitrogen supply of plankton populations in stratified, frontal and tidally mixed shelf waters. Mar. Ecol. Prog. Ser. 17: 201-213

Jones, J. G., Simon, B. M. (1975). An investigation of errors in direct counts of aquatic bacteria by epifluorescence microscopy, with reference to a new method for dyeing membrane filters. J. appl. Bact. 39: 317-329

Kupferman, S. L., Becker, G. A., Simmons, W. F., Schauer, U., Marietta, M. G., Nies, H. (1986). An intense cold core eddy in the North-East Atlantic. Nature, Lond. 319: 474-477

Le Groupe Tourbillon (1983). The Tourbillon experiment: a study of a mesoscale eddy in the eastern North Atlantic. Deep-Sea Res. 30: 475-511

Lochte, K. (1985). Biological studies in the vicinity of a shallow-sea tidal mixing front. III. Seasonal and spatial distribution of heterotrophic uptake of glucose. Phil. Trans. R. Soc. Lond. Ser. B 310:445-469

Lochte, K., Turley, C. M. (1985). Heterotrophic activity and carbon flow via bacteria in waters associated with a tidal mixing front. In: Gibbs, P. E. (ed.) Proceedings of the 19th European Marine Biology Symposium. Cambridge Univ. Press, Cambridge, p. 73-85

Lorenzen, C. J. (1967). Determination of chlorophyll and phaeopigments: spectrophotometric equations. Limnol Oceanogr. 12: 343-346

Mittelstaedt, E. (1987). Cyclonic cold-core eddy in the eastern North Atlantic. I. Physical description. Mar. Ecol. Prog. Ser. 39: $145-152$

Nagata, T. (1986). Carbon and nitrogen content of natural planktonic bacteria. Appl. environ. Microbiol. 52: 28-32

Nelson, D. M., Ducklow, H. W., Hitchcock, G. L., Brzezinski, M. A., Cowles, T. J., Garside, C., Gould, R. W., Jr., Joyce, T. M., Langdon, C., McCarthy, J. J., Yentsch, C. S. (1985). Distribution and composition of biogenic particulate matter in a Gulf Stream warm-core ring. Deep Sea Res. 11: $1347-1369$

Novitsky, J, A., Morita, R. Y. (1978). Possible strategy for the survival of marine bacteria under starvation conditions. Mar. Biol. 48: 289-295

Olson, R. J. (1981). Differential photoinhibition of marine nitrifying bacteria: a possible mechanism for the formation of the primary nitrite maximum. J. mar. Res. 39: 227-238

Ortner, P. B., Hulburt, E. M., Wiebe, P. H. (1979). Phytohydrography, Gulf Stream rings, and herbivore habitat organisms. J. exp. mar. Biol. Ecol. 39: 101-124

Peele, E. R., Murray, R. E., Hanson, R. B., Pomeroy, L. R. Hodson, R. E. (1985). Distribution of microbial biomass and secondary production in a warm-core Gulf Stream ring. Deep Sea Res. 32: 1393-1403

Robinson, A. R. (ed.) (1983). Eddies in marine science. Springer Verlag, Berlin

Shuman, F. R., Lorenzen, C. F. (1975). Quantitative degradation of chlorophyll by a marine herbivore. Limnol. Oceanogr. 20: 580-586

Sieburth, J. McN., Smetacek, V., Lenz, L. (1978). Pelagic ecosystem structure: heterotrophic compartments of the plankton and their relationship to plankton size fractions. Limnol. Oceanogr. 23: 1256-1263

The Ring Group (1981). Gulf Stream cold-core rings: their physics, chemistry and biology. Science 212: 1091-1100

Turley, C. M., Lochte, K. (1985). Direct measurement of bacterial productivity in stratified waters close to a front in the Irish Sea. Mar. Ecol. Prog. Ser 23: 209-219

Turley, C. M., Lochte, K. (1986). Diel changes in the specific growth rate and mean cell volume of nature bacterial communities in two different water masses in the Irish Sea. Microb. Ecol. 12: 271-282

Turley, C. M. Newell, R. C., Robinson, D. B. (1986). Survival strategres of two small marine ciliates and their role in regulating bacterial community structure under experimental conditions. Mar. Ecol. Prog. Ser 33: 59-70

Utermöhl، H. (1958). Zur Vervollkommnung der quantitativen Phytoplankton-Methodik. Mitt. int. Verein. theor. angew. Limnol. 9: 1-38

Ward, B. B., Olson, R. J., Perry, M. J. (1982). Microbial nitrification rates in the primary nitrite maximum off southern California. Deep Sea Res. 29: 247-255

Wiebe, P. (1976). The biology of cold-core rings. Oceanus 19 $69-76$

Wiebe, P. H. (1982). Rings of the Gulf Stream. Scient. Am. 246 . $60-70$ 